\title{
THE ASPECTS OF THE MYTHOLOGICAL DISCOURSE OF ONE-ACT DRAMAS BY S. CHERKASENKO
}

\author{
Mariya Moshnoriz \\ Lecturer at the Department of Linguistics, Vinnytsia National Technical University, Ukraine \\ e-mail: opanasuk.mm@gmail.com, orcid.org/0000-0001-6850-9610
}

\section{Summary}

In modern literature studies much attention is paid to the study of mythopoetics of modernist writers, whose mythologism serves as an artistic technique and as one of the signs of their worldview. The article researches the realization of the eschatological myth in one-act dramas by S. Cherkasenko, reveals the artistic features of the author's eschatological model of the world, in which eschatology provides for the temporary destruction of the established time order to acquire a new time cycle. It was found that in society eschatological hopes are cyclical in nature and are mostly activated at the turn of the century. The article describes the eschatological motifs of one-act dramas by S. Cherkasenko; reveals the reasons of destruction of the universe; analyzes apocalyptic events as a set of values and norms, the violation of which leads to the inevitable end of the kin and the historical epoch in general. The analysis outlines a number of images and motifs which are associated with the binary oppositions "past - present", "light - darkness" and proves the author's use of biblical and national and cultural mythologemas borrowed from the Romantic era. It was studied that in the work solar symbolism is associated with the idea of purification, salvation, hope for a new life, and darkness (night) symbolizes worldly suffering, spiritual darkness, hopelessness.

Keywords: mythopoetics, mythology, mythologema, symbol, eschatology, drama.

\section{DOI: https://doi.org/10.23856/3851}

\section{Introduction}

In the late XIX and early XX centuries, in the era of development of national consciousness, culture and its sources, writers were actively cultivating mythopoetic thinking. One of the reasons for the orientation of literature to the myth is the writers' attempt to completely comprehend the archetypes of life, to create general models of literary presentation of the relationship between a man and the world. Most outstanding masters of the word of the late XIX and early XX centuries ideologically, aesthetically and emotionally assimilated the sources of mythology and folklore. The artistic presence of mythopoetics within the literary transformation of reality requires its special study, elucidation of the relationship between mythology and literature, the functions of myth in literature. This is the increased interest in the work of Spiridon Cherkasenko, who has not been studied in this aspect. Achieving the goal requires a number of tasks: to explore the author's eschatological model and to reveal the eschatological motifs in the one-act dramas "Povynen", "Zhakh".

Spiridon Cherkasenko (poet, novelist, playwright, critic, public figure) entered the history of Ukrainian drama as the author of about 20 plays. Most researchers note that S. Cherkasenko's favorite literary genre was drama, as evidenced by the quantitative indicator of his dramatic works.

In general, S. Cherkasenko's drama has been studied enough by (Baraban, 1994), (Demyanivska, 1995),(Veselovska, 1997),(Zhytska, 1999),(Kudryavtsev, 2003),(Malyutina, 1991), (Moroz, 1993), (Oliynyk, 1994), (Sverbilova, 2009), (Khorob, 2000), (Shkola, 2001) etc. 
S. Khorob considers S. Cherkasenko's dramatic works "in a typological context through the prism of European modernist trends" and decodes the Christian symbolism of S. Cherkasenko's dramas for the first time (Khorob, 1999: 121). The scientist notes the national coding of the symbols of S. Cherkasenko's dramas, which "become an artistic expression of acute public and social problems" (Khorob, 1999: 133).

N. Malyutina, T. Sverbilova focused on the issues of genre and style transformations of dramatic works by S. Cherkasenko and sometimes for the first time analyzed a number of dramatic texts by S. Cherkasenko.

G. Veselovska, T. Zhytska studied the significance of S. Cherkasenko's work in the theatrical process of Ukraine in the first third of the XX century. In particular, T. Zhytska highlighted the aesthetic principles of drama and the peculiarities of the stage incarnations of the writer's plays, the achievements of Cherkasenko as a critic.

The mythological aspect of S. Cherkasenko's artistic comprehension of dramas has been studied selectively: V. Antofiichuk, O. Kohut, O. Kuzma, A. Niamtsu and others. In the article "Evangelical Archetype of Betrayal in the Drama "Tsina Krovi" V. Antofiichuk emphasizes the manifestation of the archetype of betrayal in the drama, which S. Cherkasenko "complicates with numerous national and historical, spiritual and moral motivations, excluding from the content of the drama traditional, evangelical interpretation of Judas' betrayal" (Antofichuk, 1996: 52). O. Kuzma proved the intertextual richness of the drama "Tsina Krovi" by S. Cherkasenko and proved that the drama is "a kind of a text-"palimpsest", which clearly distinguishes the biblical intertext” (Kuzma, 2014: 159).

It is worthn mentioning the dissertations of V. Shkola (Shkola, 2014), which traced the evolution of the individual style of the writer, revealed the genre and style features of the writer's drama, and O. Oliynyk (Oliynyk, 1994), who analyzed various aspects of symbolization of artistic action in dramatic works. In particular, V. Shkola considers the mythological level of the dramas "Kazka Staroho Mlyna" (1914) and "Tsvit Paporoti" (1926), noting the combination of fiction with reality, "modern collisions and ancient folk motifs" (Shkola, 2001:83). Arguing that fact, the researcher singled out mythological world plots, images (Judas, Don Juan) and motifs (Prometheanism) in S. Cherkasenko's dramatic art.

In her dissertation, S. Stezhko analyzed the question of the transformation of the steppe mythology in S. Cherkasenko's historical dramas ("Severyn Nalyvaiko", "Pro Shcho Tyrsa Shelestila"). Let us agree with the researcher that in his dramatic works S. Cherkasenko reproduced the "national and mythological concept of the past as the "golden age"of the Ukrainian nation" (Stezhko, 2018:151).

\section{The eschatological motifs of the sketch "Zhakh"}

From 1901 to 1910 S. Cherkasenko taught at the Lidiivka mines (modern Lidiivka mine in Donetsk). During this period the dramatic works "Zhakh", "Povynen", "Khurtovyna" (1908) appeared. These works were devoted to the revolutionary events of 1905-1907, which, in our opinion, contributed to the author's use of eschatological motifs. Among the one-act plays the most popular were "Vechirnii Hist", "Chudo Sviatoho Mykolaia", "Novi Shliakhy", "Zhakh". "The plays were successfully staged in the early 20's not only in folk theater groups, but also in such well-known theaters as the Mykola Sadovsky Theater, the First National Theater of Taras Shevchenko, The I. Franko Theater and others" (Baraban, 1994: 44). In Ukrainian literature of the beginning of the XX century this genre was used by Lesia Ukrainka ("Proshchannia", "Aisha and Mohammed"), Oleksandr Oles ("Pry Svitli Vatry", 
“Misiachna Pisnia”, “Osin”, “Osinnioi Nochi”), L. Starytska-Cherniakhivska ("Sapfo”), "Nocturn") and others.

S. Khorob singled out the following features of the one-act dramas: a small size, coverage of one episode, a limited amount of actors, which "gives the one-act drama unity and uniqueness of the overall effect of the plot line, concentration of the leading thought, deeper psychologism" (Khorob, 2008: 78). Among a number of small genre forms dramatic dialogues, dramatic drawings, dramatic studies, dramatic ballads, and dramatic sketches are distinguished. S. Cherkasenko calls his one-act play "Zhakh" a dramatic sketch, and "Povynen" is called a dramatic study, using the techniques and means of poetics of symbolist drama. We agree with S. Khorob and M. Kudryavtsev that "the images of the work are abstract and symbolic, in each of them we see the bearers of certain ideological beliefs, embodying the social character of the heterogeneous and divided Ukrainian society, agitated by the revolution" (Kudryavtsev, 2003: 150).

In the dramatic sketch "Zhakh" the author "psychologically and linguistically accurately conveyed the very state of expectation, insecurity and horror of the family, which, recollecting the past, as if confess to each other in the committed sins or crimes" (Khorob, 2008: 82).

In one of the letters S. Cherkasenko mentions the life prototypes of "Zhakh" (the sons of the Sich family, who secretly romanced with mercenaries, as I later learned, and even endured shameful scandals, when the "fruit of unhappy love" of poor mercenary, was not once found on the porch at night and with his "protest" woke everyone up in the house" (Kotyash, 2013: 78)), which he later used to write a dramatic study. The eschatological motif in the drama is conveyed through the nightly horrible emotional trials of the landowner's family, who are awaiting retribution from the workers offended by their eldest and middle sons at any moment. Through the psychological experiences of one family, the author depicts the moral state of the society against the background of revolutionary events. S. Khorob points to S. Cherkasenko's use of expressionist techniques in neo-naturalistic and symbolist dramas ("Zhakh", "Povynen"), where a person's personality appears against the background of mystical and visionary, eccentric circumstances and situations with feelings of fear, remorse, humility, and the dramatic action dissolves in the aspirations and dreams of a speedy completion of this superhuman ordeal" (Khorob, 2000: 45).

The author deals with the problem of extermination of the psychology of slavery in a dramatic way, associating the wrath of the offended mercenaries with the wrath of God, and the Judgment of God as a just punishment of the offended to their oppressors. The plot of the work is reminiscent of the Christian plot of Judgment Day, when everyone will be punished for their actions and deeds. All the members of the family are awaiting the punishment for the shameful actions of the Elder and the Middle Brothers. During the night, everyone experiences a range of emotions from fear, despair, obedience to rage, and darkness, silence, limited space of the room, constant fear and horror of each sound outline the space, creating an apocalyptic mood of the work: «Менший. Ви жорстокі люде. Ви з людьми поводилися, як із собаками, а зараз ганебно тремтите, чекаючи кари від них» (Cherkasenko, 1991: 356). The apocalyptic version of the plot combines a number of biblical eschatological motifs: blurring the line between night and day («Менший. Сидіти щоночі на чатах, тремтіти від кожного подиху вітру, обертати ніч у день, а день у нічсе божевілля» (Cherkasenko, 1991: 356)); the change of a family structure: mercenaries abandon children at their abusers' places, sons raise a hand to a father (Старший і Середульший. (схоплюються розлютовані) Чи замовкнеш, дідьку старий! (підступають до батька). «Батько. ... Нехай б'ють, зневажають батька» (Cherkasenko, 1991: 361)); the events take place at night and are associated with darkness as an immeasurable, frightening temporal characteristic. 
The change in the established time order is connected with the eschatological motif in the drama, time is divided into past and present: the past is associated with paradise («Батько. Ми з старою вік прожили, й за нашої пам’яті не було, щоб наймит пішов від нас без заробленого ним, з прокльонами, з нахвалкою й погрозами. Ми жили лагідно, по-божому, й люди нас знали, й ми їх знали...» (Cherkasenko, 1991: 360)), and the present time of action (1905-1907) is associated with hell («Батько. Ми не зазнавали таких часів. Ніколи наймити не нахвалялися палити нас, а наймички не кидали дітей не ганках» (Cherkasenko, 1991: 356)). With the help of the opposition "light - darkness" the author characterizes the "light" past and the dark present.

The opposition "light - darkness" is interpreted as the destruction of the human soul, the destruction of morality in society: «Менший. Хочете бути людьми, хочете бути спокійними поодчиняйте двері й вікна серця вашого! Геть зневагу до людей, геть запеклість! Смійтесьне дивіться вовками, співайте - не мовчіть понуро, дайте приступу свіжого повітря, весні, що пишно розвивається там, поза межами нашої тюрми» (Cherkasenko, 1991: 357). The words of the younger brother point the way from the darkness of the soul to the light, to a quiet and peaceful life in the future. Only such changes in a person and in society will save from retribution, because you cannot hide from your sins even behind a few locks.

The eschatological motif is also seen in the details of the interior of the house, which are mentioned in the remarks - «двері зачинені на засув, вікна знадвору закрито віконницями» (Cherkasenko, 1991: 356). The closed doors serve as a border, perform the function of feigned protection from the real world, in which retribution awaits. The closed windows indicate the isolation of the family from the outside world, the closed souls of the heroes indicate the isolation from the penetration of new views. The members of this family are not ready for new changes in society, except for the Yonger Brother who «має чисту, кришталеву душу, не зіпсовану огидою життя вдачу» (Cherkasenko, 1991: 347) and democratic views on life. That is why he was the first, after an anxious night, to see the sunlight shining through the closed shutters, which the Elder Son perceived as a fire of just retribution for his sins. In the work, the solar symbolism is associated with the idea of purification, salvation, hope for a new life, because with the advent of light in the room, all emotional tension disappears. In contrast, darkness (night) symbolizes earthly suffering, spiritual darkness, hopelessness.

\section{The mythologema of sacrifice in the study "Povynen"}

The eschatological motif is also reproduced in the dramatic study "Povynen", in which darkness is associated with a "dark, difficult period" in the life of a miner's family and a miner's settlement. After all, it was at night that soldiers were sent to stop the miners' rebel, and this is their most important time in the struggle for social justice, a time that requires citizen activism. Therefore, it is understandable that the miner's son wants to help his "comrades", despite a serious disease and anticipation of his death: «Син. Я належу їм і через їх тільки вам. Їхнє горе - ваше горе, їхнє щастя - ваше щастя. Власне горе, власне щастя ніщо. Моя поміч тепер найбільше потрібна. Я йду!» (Cherkasenko, 1991: 371). The son's action agrees with the biblical motif of Jesus Christ's sacrifice for the salvation of mankind. For parents, such an act of the son is not clear, and therefore they want to make the son stay at home at this difficult time. The mother who is the guardian of the hearth, like no other feels the death of her son, which is announced by disturbing dreams («Мати. ... Ні, давно вже не бачила (у сні - доп. наше - М. М.) нічого гарного. Мабуть, перевелося на світі все гарне і верзеться саме лихе ...» (Cherkasenko, 1991: 364)). In particular, the mythological ornithological image of 
a raven, which the mother saw in a dream, marks a premonition of trouble, misfortune, death: «Мати. Місячна ніч і тиша. Якась страшна тиша. I місяць червоний-червоний. I сніг червоний... I досі в очах мають ті крила (крука)» (Cherkasenko, 1991: 363). In Slavic mythology, red is associated with the blood of soldiers who died in the battle for their people, and in Christian mythology it is a symbol of the male firstborn, a symbol of suffering, the shed blood of the Son of God for the salvation of mankind. The author focuses on the mother's suffering who foresees the death of her only son. The mother, in contrast to the biblical Virgin Mary, could not tolerate the sacrifice of her son for the sake of others, that is why she strongly opposed the departure of her son to the mine, feeling his death: «Мати. Його вб'ють ... Я знаю. Чує моє серце, що він не вернеться» (Cherkasenko, 1991: 371). She could not accept it till the last, so she forced the father to go and save their only son: «Мати. Я побіжу туди! Я захищу його, я обрятую його! О сину мій! Я приверну його своїми сльозами! Він не лихий. Він зглянеться ...»(Cherkasenko, 1991: 372). Until the climax (the comrades brought a dead son), the mother's remarks resemble mourning for the dead. The author dramatically modeled the death of the son as the extinguishing of a lamp on the family table. And again S. Cherkasenko connects the anagnorisis of the study with the solar symbolism («Менша дочка. Вже ранок ... ніч минула ... я бачила, як сходить сонце ...» (Cherkasenko, 1991: 372)), which inspires with hope for better changes in the future, the advent of justice in society, through the death of the son.

\section{Conclusions}

Thus, in the one-act dramatic works of S. Cherkasenko the eschatological motifs caused by the revolutionary events in the society are dramatically reproduced. The plot of "Zhakh" has an apocalyptic character with biblical eschatological motifs: a change in the established time order, which causes the blurring of the line between night and day, a change in the family structure, limited space where events take place, fear and horror of every sound exist. The biblical motif of sacrifice formed the basis of the plot of the study "Povynen". And the namelessness and impersonality of the heroes Father, Mother, Daughter-in-law, Sons, Daughter is a manifestation of the symbolist generalization. In the works special attention is paid to the solar symbolism, which is associated with the idea of purification, salvation, hope for positive changes in life.

\section{References}

Antofiichuk V., Niamtsu A. (1996). Yevanhelski motyvy v ukrainskii literaturi kintsia XIX-XX st. [Evangelicalmotives in Ukrainian literature of the late XIX-XXcenturies]. Chernivtsi. [in Ukrainian] Baraban L. I. (1994). Folklorni elementy dramaturhiyi Spyrydona Cherkasenka [Folklore elements of Spiridon Cherkasenko's drama]. Academic Journal “Folk Art and Ethnology”. № 1. 44-52. [in Ukrainian]

Veselovska H. I. (1997). Ekspresionizm rannoyi dramaturhiyi Spyrydona Cherkasenka [Expressionism of the early dramaturgy of Spyrydon Cherkasenko]. Dyvoslovo. 1-14. [in Ukrainian] Demianivska L. (1995). Khudozhni poshuky v ukrainskii dramaturhii XX [Artistic research in Ukrainian drama of the early twentieth century]. Ukrainska literatura: Materialy 1 konhresu MAU. 133-150. [in Ukrainian]

Zhytska T. (1999). Istorychna dramaturhiya Spyrydona Cherkasenka [Historical drama of Spiridon Cherkasenko]. Kyyivska starovyna. № 5. 127-134. [in Ukrainian] 
Kohut O. V. (2010) Arkhetypni syuzhety y obrazy v suchasniy ukrayinskiy dramaturhiyi (1997-2007 rr.): monohrafiya [Archetypal storys and images in modern Ukrainian drama (1997-2007): monograph]. Rivne : NUVHP. [in Ukrainian]

Kotyash I. A. (2013). Spyrydon Cherkasenko, avtobiohrafichni tvory, literaturnyy protses, biohrafichna sytuatsiya [Spiridon Cherkasenko, autobiographical works, literary process, biographical situation]. Literatura. Dity. Chas. V. 4. 75-80. [in Ukrainian]

Kudryavtsev M. H. (2003). Ideyni koliziyi u dramaturhiyi Spyrydona Cherkasenka [Ideological collisions in Spiridon Cherkasenko's drama]. Krayeznavstvo, № 1-4. 150-167. [in Ukrainian] Kuzma O. YU. (2014). Intertekstualnist dramy S. Cherkasenka "Tsina krovi” [Intertextuality of drama of S. Cherkasenko "Blood price”]. Suchasni problemy movoznavstva ta literaturoznavstva. V. 19. 155-159. Retrieved from : http://nbuv.gov.ua/UJRN/spml_2014_19_28. [in Ukrainian]

Malyutina N. P. (2006). Ukrayinska dramaturhiya kintsya XIX pochatku XX stolittya: aspekty rodo-zhanrovoyi dynamiky [Ukrainian drama of the end of the XIX-beginning of the XX century: aspects of genus-genre dynamics]. Odesa: Astroprynt. [in Ukrainian]

Myshanych O. V. (1991). Spyrydon Cherkasenko (1876-1940). Slovo i chas, № 7. 19-29. [in Ukrainian]

Moroz L. (1993). Pro symvolizm v ukrayinskiy dramaturhiyi: (pro pyesy "Zhakh”, “Kazka staroho mlyna", "Pro shcho tyrsa shelestila" S. Cherkasenka) [About symbolism in Ukrainian dramaturgy: (about the stage play "Zhakh", "Kazka staroho mlyna", "Pro shcho tyrsa shelestila” by S. Cherkasenko)] Suchasnist, № 4. 94-106. [in Ukrainian]

Oliynyk O. I. (1994). Pochatky symvolizmu v ukrayinskiy drami: (na materiali tvorchosti O. Olesya ta S. Cherkasenka) [The beginnings of symbolism in Ukrainian drama: (on the material of O. Oles and S. Cherkasenko)]. PhD thesis. Kyiv. T. Shevchenko Institute of Literature. [in Ukrainian]

Sverbilova T., Malyutina N., Skoryna L. (2009). Vid modernu do avanhardu: zhanrovo-stylova paradyhma ukrayinskoyi dramaturhiyi pershoyi tretyny XIX stolittya [From Art Nouveau to the Avant-Garde: Genre and Style Paradigm of Ukrainian Drama of the First Third of the 20th Century]. Cherkasy. [in Ukrainian]

Stezhko S. O. (2018). Kontseptsiya istorychnoho mynuloho v ukrayinskiy dramaturhiyi 1920-1930 rokiv (S. Cherkasenko, L. Starytska-Chernyakhivska, I. Mykytenko, M. Irchan) [The concept of the historical past in the Ukrainian drama of the 1920 - 1930(S. Cherkasenko, L. Starytska-Chernyakhivska, I. Mykytenko, M. Irchan)]. PhD thesis. Kyiv. T. Shevchenko national university of Kyiv. [in Ukrainian]

Khorob S. I. (2008). Ukrayinska odnoaktna drama: vymiry struktury modernist skoho tekstu. Bibliya i kultura: Zbirnyk naukovykh statey - Scientific proceedings. Chernivtsi: Ruta, V. 10. 78-89. [in Ukrainian]

Khorob S. I. (2000). Slovo-obraz-forma: u poshukakh khudozhnosti [Word-image-form: in search of art]. Literaturoznavchi statti i doslidzhennya. Ivano-Frankivsk: Play. [in Ukrainian] Khorob S. I. (1999). Ukrayinska dramaturhiya [Ukrainian drama]. Kriz vymiry chasu. Zbirnyk statey - Scientific proceedings. Ivano-Frankivsk: Lileya-NV. [in Ukrainian]

Cherkasenko S. F. (1991). Tvory: v 2 t. Poeziya. Dramatychni tvory [Works: in 2 volumes. Poetry. Dramatic works]. V. 1. Kyiv: Dnipro. [in Ukrainian]

Shkola V. M. (2001). Dramaturhiya Spyrydona Cherkasenka (evolyutsiya indyvidualnoho stylyu) [Drama by Spiridon Cherkasenko (evolution of individual style)]. PhD thesis. Kyiv : Znannya Ukrayiny. [in Ukrainian] 